\title{
The Hyponymy of Word Containing Palakependhem Concept in Javanese
}

\begin{abstract}
Sri Nardiati
Balai Bahasa Daerah Istimewa Yogyakarta Indonesia

Email: Nardiatisri534@gmail.com

ABSTRACT

This research is important because it refers to food substitutes for (traditional) Javanese. However, the name and concept of palakependhem is almost forgotten by its speakers. In fact, the term palakependhem is not yet included in the Javanese Dictionary (Bausastra Jawa). The aim of this study is to describe a set of leksem that is covered in palakependhem, its shared meaning and diagnostics, and its hierarchical structure. The approach used is intentional with the contextual method and meaning component analysis. The theory used is the hyponymy relationship. The result shows that a set of leksem covered in palakependhem totaled, at least, fourteen. Its existence builds a branched and unbranched hierarchy structure on the basis of shared meaning and its disgnostic meaning. The result is beneficial to the development of lemma and refinement of explanations of lemma in the dictionary. Theoretically, the result of this study can be used as material for developing linguistic theory, especially semantics of languages in the archipelago.
\end{abstract}

Keywords: hyponym, superordinate, shared meaning component, diagnostic meaning component

\section{INTRODUCTION}

This research is entitled "The Hyponymy of Word Containing Palakependhem Concept In Javanese". The palakependhem term corresponds to 'tubers as substitute food' for Javanese people. The object of this research is important because it refers to staple food substitutes. However, its existence is almost forgotten by Javanese people. The kalakependhem lemma has not been recorded in the Javanese Dictionary [1]. According to Kamus Besar Bahasa Indonesia (online) it is stated that the palakependhem lemma is explained 'intercropping plants whose fruit is in the ground (such as cassava, potatoes). "This explanation is not entirely true because there are types of tubers, including pala kependhem which is not planted using intercropping systems, such as uwi, gembili, gembolo. In addition, to the author's knowledge, the semantic aspects of this object have not been studied.

Research findings relating to hyponymy are still limited in number. However, research related to meaning components is quite a lot. The research result on meaning components often includes a study of hierarchical structure. Thus, the research finds out about the highest status of lexeme and underneath it. Therefore, the result of the study has implicated lexemes with hyponym status or subordinate status and hyperonym status or superordinate status.

The article which examines hyponymy, among other things, is entitled "Kehiponiman Verba yang Menyatakan Makna 'Membawa' dalam Bahasa Melayu Betawi" by [2]. It is said that the lexeme which becomes the superordinate cannot always be reversed by its hyponym [2]. The statement is biased so that it can shake up the findings of hymnologists. One of hymnologists is [3] who argues that the words which are hyponymized in a sentence can be dubbed with words that become their hyperonyms because the meanings of hyperonym are implied their hyponym meaning.

The research on hyponymy with the title "Hiponimi Kata Mencuci dalam Bahasa Indonesia" is also carried out by [4]. The analysis is only limited to meaning component analysis. In this case, there is no evident showing of inclusion relation that has an effect on a formation of lexeme hierarchy structure. 
In addition, a study entitled " Leksikon Bermakna 'Aktivitas Telinga' dalam Bahasa Jawa" by Nurlina (2012). It is found out that the research is lack of accuracy. Since there is a finding stating that " hyponym relation diagram of ear sensory activity", the ear lexeme as superordinate or hyperonym as the highest lexeme. Below it, there is semantic features NOT DELIBERATELY which carries rungokake, simak, nguping, tilingake lexeme and DELIBERATELY which carries rungu/krungu, krungu-krungu lexeme [5]. The correction is rungokake, simak, nguping, tilingake has DELIBERATELY component, while rungu/krungu, krungu-krungu has NOT DELIBERATELY component. This fact provokes the reader to argue that the arrangement of hyponymy hierarchy structure is not following the formulas carried out by previous experts since, in addition to the reversal, there is also a mixture between the distinguishing meaning component and lexeme name that is being analyzed.

The next study is conducted by [6] with the title "Perian Semantik Leksem-Leksem yang Berkonsep 'Bermusik dengan Mulut dalam Bahasa Jawa". The study is based on an analysis of meaning components to hierarchical structure (hyponym). The study uses a marker * (asterisk) which states that meaning components are not relevant to certain lexemes. However, these markers are not used in the analysis. In addition, in the analysis, it is stated that a set of lexemes as the data is grouped into two $\varnothing$ (zero) fields. Zero cannot explain the field, zero $\varnothing$ will refer to the lexeme which is superordinate, but cannot be lexicalized.

The next study is conducted by [7] entitled " Medan Makna Aktivitas Tangan Bahasa Melayu Pontianak ". Her research says that hand activity is divided into seven groups: holding, touching, taking, carrying, laying down, giving, and hurting. Hurting activity includes the head and its parts, neck, and body. However, the description of the meaning components in each lexeme is not systematic so that the readability is low. For this reason, it is necessary to have a matrix of meaning components so that value of meaning components of each lexeme to its hierarchical structure is easily understood.

The next study is carried out by Sary (2015) with the title " Analisis Komponen Medan Makna Rumah (Kajian Semantik)". The study encompasses from meaning components of lexemes to the hierarchical structure of a set of lexemes that has a house concept. Furthermore, it is mentioned that rumah, gerha, wisma lexeme do not have meaning component. The existence of gerha lexeme is often as a name so that its meaning components are not described. However, rumah and wisma have still existed so that they have meaningful components.
In the analysis also mentioned that rumah lexeme occupies the highest hierarchy. This proves that the analysis conducted has entered the hyponymy relationship [8].

From these explanations, it is clear that a study of meaning components and hyponymy of lexeme of palakependhem concept in Javanese is necessary. In this study, an intensional approach with contextual method and meaning component analysis is used. In the analysis marking technique is used.

According to Nida [9], the intentional approach focuses on the conceptual structure of each lexeme. The theory of hyponymy follows Lyon's opinion [3] as used by [10] entitled "Telaah Baru dalam Tata Hubungan Leksikal Kehiponiman dan Kemeroniman ". In the theory, it is explained that lexemes which are cohyponyms of the same superordinate can be contrasted in meaning for their same hyponym. Components of shared meaning are spread over a set of lexemes that are covered within it. According to [9] and [3], the existing meaning contrast results in the formation of a hierarchical structure.

The meaning of a word as subordinate or hyponym status is contained or covered in the meaning of other words which become superordinate or hyperonym. Therefore, words that become hyponym or subordinate in a context can be dubbed with words that become superordinate or hyperonyms. According to [9], the relation of lexeme meaning which has subordinate and superordinate status is classified as the relation of inclusion or coverage. The meaning component contained in subordinate includes in superordinate lexeme meaning component that impacts on unidirectional engagement. In sentence context, words that become hyponym or subordinate can be dubbed with words that become hyperonym or superordinate, but not vice versa [3]. This set of lexemes is related horizontally and vertically. This relation is formed based on contrast and comparison procedures [9].

The problem of this research is the forms of a set of words/lexemes that are covered in pala kependhem. The problems also cover its components of shared meanings and components of diagnostic or distinctive meanings and hierarchical structure.

The result of this study can be used as material for developing lemma and refining lemma in both Javanese and Indonesian dictionaries. The results of this study can be used to refine the dictionary lemma explanation. Furthermore, the results of this study can also be used to develop semantic theories of archipelago languages. 
The method of distribution is used in the data appointment, the determining tool is part of the language being analyzed. This method is used by listening technique followed by note technique. The equivalent method is used in the analysis, namely the analysis method with determinant in the form of reality designated or referred to by the language itself [11]. The collected data is tested by the contextual method [3] in the form of $X$ klebu jinising $Y$ ' $\mathrm{X}$ included / classified type $\mathrm{Y}$ '. In this case, $\mathrm{X}$ is filled with words that become hyponyms, while $\mathrm{Y}$ is filled with words that become superordinate or hyperonyms.

In the analysis meaning component analysis method is used by using the marker technique on each semantic reaction contained in each lexeme. The + (plus) sign indicates a component of meaning. The - (minus) sign indicates there is no meaning component. The 0 (zero) sign marks the neutrality of meaning components in certain lexemes. Words or lexemes are written in italics. The meaning components are written in capital letters. Similar writing techniques are commonly used by semantic researchers, among others, [12], [13].

\section{RESULT AND DISCUSSION}

The results shows that the number of tubers or pala kependhem are fourteen, as follows.

\begin{tabular}{|c|c|}
\hline enthik & [ənț!̣] \\
\hline tales & [taləs] \\
\hline kimpul & [kimpUl] \\
\hline uwi & [uwi] \\
\hline gembili & [gəmbili] \\
\hline gembolo & [gəmbolo] \\
\hline gadhung & [gaḍUn] \\
\hline suwek & [suwək] \\
\hline tela kaspa & [telつ kaspつ] \\
\hline tela pendhem & [tel’ pənḍım] \\
\hline midra/ganyong & [midr’]/ [gañ’n] \\
\hline garut & [gañon] \\
\hline kenthang & [kənțay] \\
\hline kleci & [klənci] \\
\hline
\end{tabular}

The set of lexemes is covered in the palakependhem lexeme. To find out their structure of the hierarchy, the meaning components are first determined through method of meaning component analysis with the marker technique as shown in the following matrix. 
1.2 TABLE OF THE MEANING COMPONENT MATRIX`A SET OF TUBE CONCEPT LEXEME’

\begin{tabular}{|c|c|c|c|c|c|c|c|c|c|c|c|c|c|c|c|c|c|c|c|c|c|c|c|c|c|c|c|}
\hline \multirow[t]{3}{*}{ No } & \multirow{3}{*}{$\begin{array}{l}\text { Dimension } \\
\text { Component } \\
\text { Lexeme }\end{array}$} & \multirow{3}{*}{$\begin{array}{c}\begin{array}{c}\text { Growth } \\
\text { Position }\end{array} \\
\text { in Soil }\end{array}$} & \multicolumn{8}{|c|}{ Type } & \multicolumn{17}{|c|}{ Form } \\
\hline & & & \multicolumn{8}{|c|}{ Stem } & \multicolumn{9}{|c|}{ Leaf } & \multicolumn{4}{|c|}{ Tube } & \multicolumn{4}{|c|}{ Bark } \\
\hline & & & 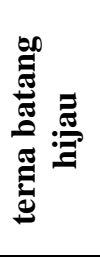 & 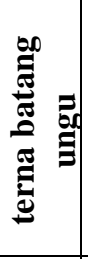 & $=$ & 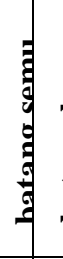 & 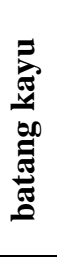 & 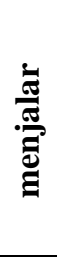 & 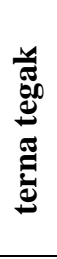 & 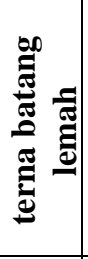 & 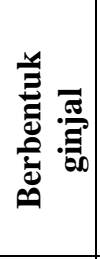 & 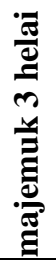 & 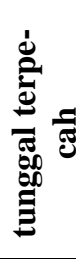 & 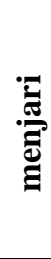 & 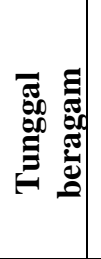 & 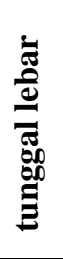 & 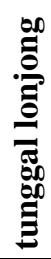 & 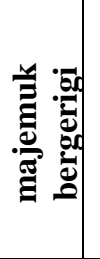 & 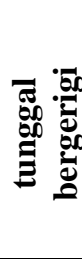 & $\frac{\grave{t}}{\mathscr{E}}$ & 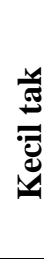 & $\overrightarrow{\bar{E}}$ & 胥 & 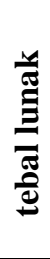 & 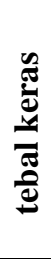 & 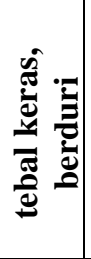 & 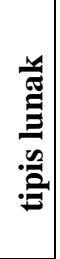 \\
\hline 1 & enthik & + & + & - & - & - & - & - & - & - & - & - & - & - & - & + & - & - & - & + & - & - & - & + & - & - & : \\
\hline 2 & tales & + & - & + & - & - & - & - & - & - & - & - & - & - & - & + & - & - & - & + & - & - & - & + & - & - & - \\
\hline 3 & kimpul & + & - & + & - & - & - & - & - & - & - & - & - & - & - & + & - & - & - & - & - & + & + & + & - & - & - \\
\hline 4 & uwi & + & - & - & + & - & - & - & - & - & + & - & - & - & - & - & - & - & - & + & - & - & - & + & - & - & - \\
\hline 5 & gembili & + & - & - & + & - & - & - & - & - & + & - & - & - & - & - & - & - & - & + & - & - & - & - & + & 0 & - \\
\hline 6 & gembolo & + & - & - & + & - & - & - & - & - & + & - & - & - & - & - & - & - & - & - & - & + & - & - & - & + & - \\
\hline 7 & gadhung & + & - & - & + & - & - & - & - & - & - & + & - & - & - & - & - & - & - & - & - & + & - & - & + & - & - \\
\hline 8 & suwek & + & - & - & - & + & - & - & - & - & - & - & + & - & - & - & - & - & - & - & - & + & - & - & + & - & - \\
\hline 9 & tela kaspa & + & - & - & - & - & + & - & - & - & - & - & - & + & - & - & - & - & - & + & - & - & - & - & + & - & - \\
\hline 10 & tela pendhem & + & - & - & - & - & - & + & - & - & - & - & - & - & + & - & - & - & - & - & - & + & - & - & - & + & - \\
\hline 11 & midra/ganyong & + & - & - & - & - & - & - & + & - & - & - & - & - & - & + & - & - & - & - & - & - & + & - & + & - & - \\
\hline 12 & garut & + & - & - & - & - & - & - & + & - & - & - & - & - & - & - & + & - & - & + & - & - & - & - & + & - & - \\
\hline 13 & kenthang & + & - & - & - & - & - & - & - & + & - & - & - & - & - & - & - & + & - & - & - & + & - & - & - & - & + \\
\hline 14 & kleci & + & - & - & - & - & - & - & - & + & - & - & - & - & - & - & - & - & + & - & + & - & - & - & - & - & + \\
\hline
\end{tabular}


1.2 TABLE OF THE MEANING COMPONENT MATRIX`A SET OF TUBE CONCEPT LEXEME’

continued

\begin{tabular}{|c|c|c|c|c|c|c|c|c|c|c|c|c|c|c|c|c|c|c|}
\hline \multirow[t]{2}{*}{ No } & \multirow{2}{*}{ lexeme } & \multicolumn{5}{|c|}{ Flesh Color } & \multirow{2}{*}{ 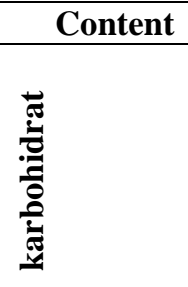 } & \multirow[b]{2}{*}{ 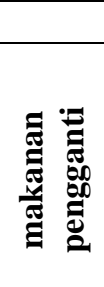 } & \multicolumn{2}{|c|}{ Funtion } & \multicolumn{4}{|c|}{ Taste } & \multicolumn{4}{|c|}{ Processing } \\
\hline & & 导 & 节 & ב & $\frac{\bar{t}}{\frac{\pi}{8}}$ & 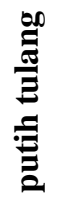 & & & 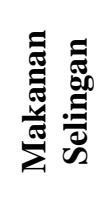 & $\underset{\Xi}{\Xi}$ & ప్ర & 怘 & $\frac{\overline{0}}{\bar{z}}$ & $\stackrel{\Xi}{\vec{\Xi}}$ & $\frac{\mathscr{Z}}{0}$ & $\frac{\mathscr{E}}{\vec{E}}$ & م0 & 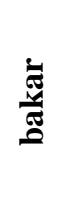 \\
\hline 1 & enthik & + & - & - & - & - & + & 0 & 0 & 0 & + & - & + & - & 0 & 0 & 0 & - \\
\hline 2 & tales & + & - & - & - & - & + & 0 & 0 & - & + & - & + & - & 0 & 0 & 0 & - \\
\hline 3 & kimpul & + & - & - & - & - & + & 0 & 0 & - & + & - & + & - & 0 & 0 & 0 & - \\
\hline 4 & uwi & 0 & 0 & - & - & - & + & 0 & 0 & - & + & - & 0 & 0 & 0 & 0 & - & - \\
\hline 5 & gembili & + & - & - & - & + & + & 0 & 0 & - & - & + & 0 & + & + & - & - & - \\
\hline 6 & gembolo & - & - & - & - & + & + & 0 & 0 & - & - & + & - & - & - & + & - & - \\
\hline 7 & gadhung & 0 & - & 0 & - & + & + & - & + & - & + & - & - & - & - & 0 & 0 & - \\
\hline 8 & suwek & - & - & - & - & + & + & 0 & 0 & - & + & - & + & - & - & + & - & - \\
\hline 9 & tela kaspa & 0 & - & 0 & - & - & + & 0 & 0 & 0 & + & - & + & - & 0 & 0 & 0 & 0 \\
\hline 10 & tela pendhem & 0 & 0 & 0 & - & - & + & 0 & 0 & 0 & - & + & 0 & - & 0 & 0 & 0 & 0 \\
\hline 11 & Ganyong/modra & - & - & - & - & 0 & + & 0 & 0 & - & - & + & 0 & + & + & - & - & - \\
\hline 12 & garut & - & - & - & - & + & + & 0 & 0 & - & + & - & - & - & + & - & - & - \\
\hline 13 & kenthang & - & - & 0 & - & 0 & + & 0 & 0 & 0 & + & - & + & - & 0 & 0 & 0 & - \\
\hline 14 & kleci & - & - & - & - & + & + & 0 & 0 & 0 & + & - & + & - & 0 & 0 & - & - \\
\hline
\end{tabular}


In the matrix it appears that meaning components of a set of lexemes can be analyzed based on eight dimensions, namely growth position; stem type; form: leaves, tubers, bark; tube color; content; function; taste; and processing. On the basis of contrast and comparison procedures, the lexemes that are covered in pala kependhem can be classified into five groups, as follows.

\subsubsection{Group I}

There are three lexemes in group I, namely enthik, tales, kimpul. If it is compared, there are components of shared meanings on the basis of
LEAF-FORM DIMENSION: SINGLE WIDTH; SKIN FORM: SOFT THICKNESS; MEAT COLOR: WHITE; TASTE DIMENSION: PULEN. If it is contrasted, there are components of diagnostic meaning on the basis of STEM TYPE DIMENSION: + GREEN for enthik lexeme, +PURPLE STEM HERBACEOUS PLANT for tales lexeme, and + GREEN-PURPLE STEM HERBACEOUS PLANT for kimpul lexeme. Superordinate is pala kependhem1. The structure of the lexeme hierarchy is shown in the following tree diagram (diagram 1).

Diagram 1. Palakependhem 1

\subsubsection{Group II}

There are four lexemes in group I, namely uwi, gembili, gembolo, gadhung. If it is opposited there is a component of shared meaning based on STEM TYPE DIMENSION: CLUMP VINES. When it is contrasted, there is a component of diagnostic meaning on basis of LEAF FORM DIMENSION: + KIDNEY FORM for $u w i$, gembili, and gembolo lexeme, + THREE BLADE
COMPOUND for gadhung lexeme. Based on the TUBE FORM DIMENSION, there is a + CYLINDER diagnostic component for $u w i$ and gembili lexeme, while + ROUND for gembolo and gadhung lexeme. The component of diagnostic meaning between gembolo and gadhung lexeme lies in TASTE DIMENSION, namely + SWEET for gembolo lexeme and + TASTELESS-CHEWY DIMENSION on gadhung. Its hierarchical structure is shown in the following diagram (diagram 2).

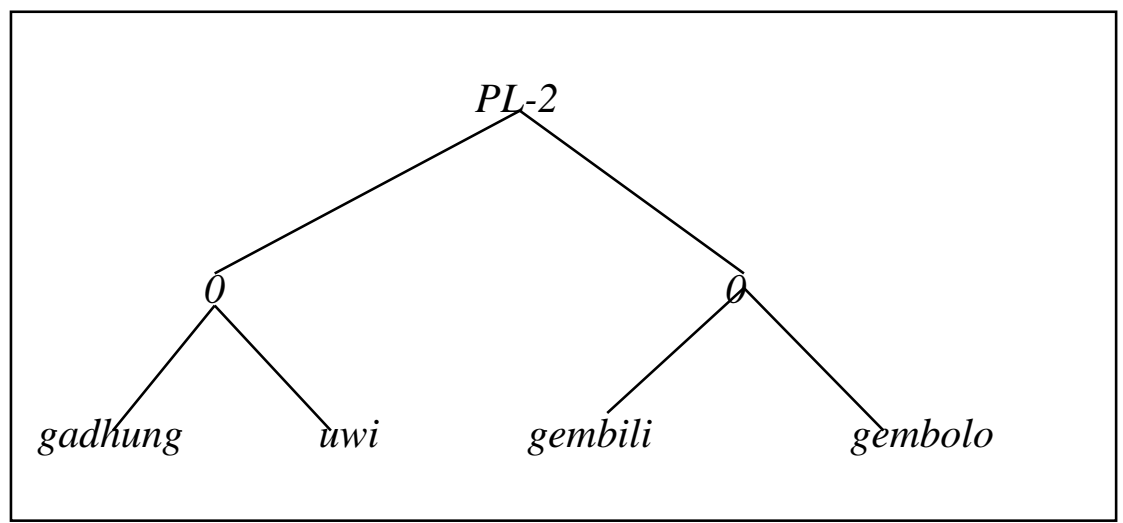

Diagram 2. Pala kependhem 2 


\subsubsection{Group III}

Group III consists of three lexemes, namely kenthang, kleci and tela pendhem. Components of shared meaning of the three lexemes can be seen from STEM TYPE DIMENSION: + WEAK STEM HERBACEOUS PLANT; based on TASTE DIMENSION: + PULEN; from PROCESSING DIMENSION: + BOIL, + STEAM, and from
BARK FORM DIMENSION: + THIN. When it is contrasted, the three lexemes have diagnostic components. From the BARK COLOR DIMENSION, on kentang 'potato' + YELLOW lexeme, on kleci: + YELLOW lexeme, + BROWN, + BLACK, on tela pendhem lexeme: + WHITE, + YELLOW, + PURPLE. (5) The hierarchical structure of the three lexemes appears in the diagram following (diagram 3 ).

\subsubsection{Group IV}

(1) Group IV consists of two lexemes, namely midra/ganyong and garut. If it is opposited, components of shared meanings can be seen from TRUNK TYPE DIMENSION: + UPRIGHT HERBACEOUS PLANT DIMENSION; BARK FORM DIMENSION: SCALY HARD THICK; PROCESSING DIMENSION: + BOIL. When it is contrasted, the two lexemes have component of diagnostic meaning from the LEAF FORM DIMENSION: + SINGLE WIDE for midra/ganyong and + SINGLE OVAL for garut; from TASTE DIMENSION: + TASTELESS for garut lexeme and + SWEET, + EMPUR for midra/ganyong lexeme. The hierarchical structure is shown in the following diagram (diagram 4).

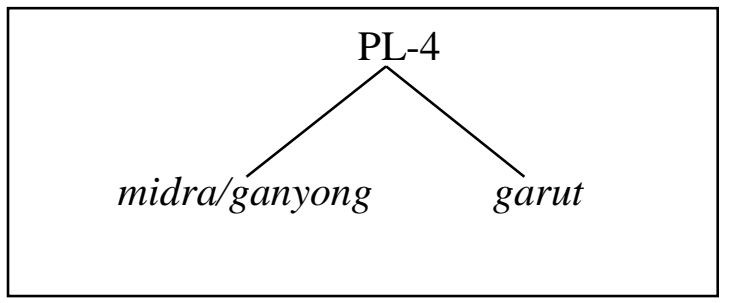

Diagram 4. Pala kependhem 4

The data shows that there are still two lexemes that have different components of meaning, namely tela kaspa and suwek. Both lexemes have shared meaning component of, from the GROWTH POSITION DIMENSION: + IN SOIL; from CONTENT DIMENSION: + CARBOHYDRATES; 0 REPLACEMENT FOOD, and 0 SNACK. The two lexemes are co-hyponym, their presence has a unbranched hierarchical structure, and they are immediately covered by superordinate lexemes. A set of lexemes which has the concept of palakependhem is illustrated in its overall hierarchical structure in the following diagram (diagram 5). 


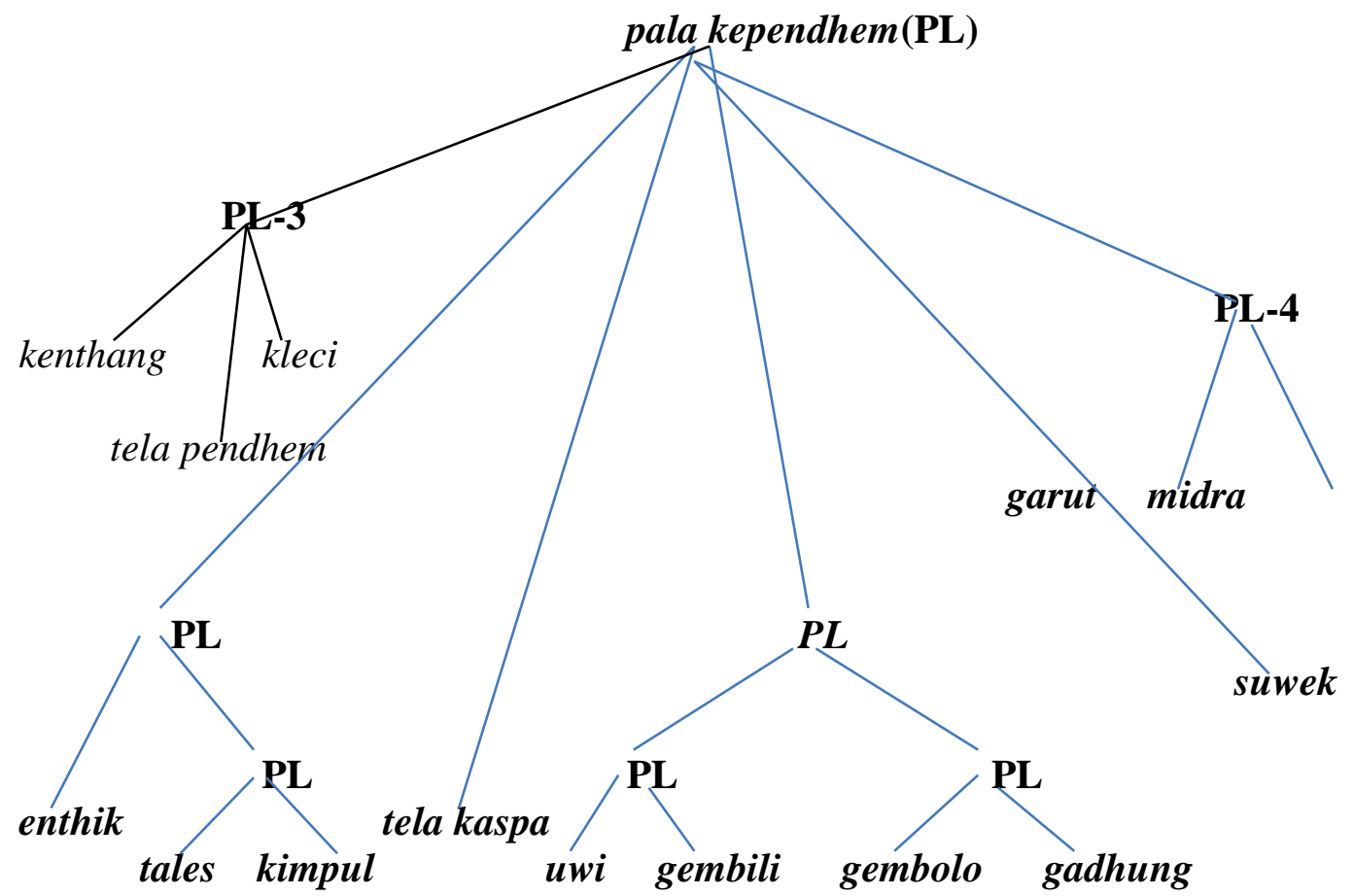

Diagram 5. Pala kependhem (PL)

\section{CONCLUSION}

In this study, fourteen lexemes that are included in pala kependhem lexeme are discovered, namely enthik, tales, kimpul, tela kaspa, uwi, gembili, gembolo, gadhung, tela pendhem, suwek, kenthang, kleci, midra, and garut. (2) Based on an intentional approach, contextual method, meaning component analysis, and vertical-horizontal procedures, the fourteen lexemes are oppposited and contrasted so that they form four branched and unbranched hierarchical structures. The unbranched hierarchy has two lexemes, namely suwek and tela

\section{REFERENCES}

[1] Tim Balai Bahasa Yogyakarta, Kamus Bahasa Jawa (Bausastra Jawa), 2nd ed. Penerbit Kanisius, 2011.

[2] R. Ekoyanantiasih, “"Kehiponiman Verba Yang Menyatakan Makna "Membawa" Dalam Bahasa Melayu Betawi," Met. J. Penelit. Bhs., vol. 13, no. 2, p. 201, 2015, doi: http://dx.doi.org/10.26499/metalingua.v13i2.

[3] J. Lyons, Semantics, 1st ed. Australia: Cambridge University Press, 1977.

[4] Sutarsih, "'Hiponim Kata Mencuci Dalam Bahasa Indonesia," Jala Bhs. J. Ilm. kaspa. Branched hierarchy has four groups. Group I has three lexemes, namely enthik, tales, and kimpul. Group II has four lexemes, namely uwi, gembili, gembolo, and gadhung. Group III has three lexemes, namely kenthang, kleci, and tela pendhem. Group IV has two lexemes, namely midra/ganyong and garut. This set of lexemes is subordinated by pala kependhem lexeme as its superordinate based on components of shared meaning based on GROWTH POSITION DIMENSION: + IN SOIL; CONTENT: CARBOHYDRATES; and FUNCTION: REPLACEMENT FOOD.

Kebahasaan, vol. 14, no. 1, pp. 1-34, 2018, doi:

https://doi.org/10.36567/jalabahasa.v14i1.184.

[5] W. E. S. Nurlina, "Leksikon Bermakna "Aktivitas Telinga" Dalam Bahasa Jawa," Suar Betang J. Kebahasaan, Kesastraan, dan Pengajarannya, vol. VII, no. 2, p. 32, 2012.

[6] D. Sutana, "'Perian Semantik Leksem-Leksem Yang Berkonsep "Bermusik Dengan Mulut" dalam Bahasa Jawa,"” Met. J. Penelit. Bhs., vol. 11, no. 2, pp. 1-26, 2013.

[7] I. Herawati, “"Medan Makna Aktivitas Tangan 
Bahasa Melayu Pontianak," Tuah Talino Menggalang Makna Dalam Karya J. Ilm. Bhs. dan Sastra, vol. 10, no. 1, pp. 1-16, 2016, doi: https://doi.org/10.26499/tuahtalino.v10i1.150.

[8] H. N. Sary, "“Analisis Komponen Medan Makna Rumah (Kajian Semantik),", Sirok Bastra J. Kebahasaan dan Kesastraan, vol. 3, no. 1, pp. 6-8, 2015, doi: https://doi.org/10.37671/sb.v3i1.49.

[9] E. A. Nida, "Componental Analysis of Meaning," in Componental Analysis of Meaning an Introduction to Semantic Structures, Paris: MOUTON, 1975, p. $15,22,23,88,89$.

[10] U. Basiroh, "Telaah Baru Dalam Tata Hubungan Leksikal Kehiponiman dan
Kemeroniman," Universitas Indonesia, 1992.

[11] Sudaryanto, "Pendahuluan: Metode Padan dan Metode Agih," in Metode dan Aneka Teknik Analisis Bahasa: Pengantar Penelitian Wahana Kebudayaan secara Linguistis, 1st ed., Thomas, Ed. Yogyakarta: Sanata Dharma University Press, 2015, p. 15.

[12] S. Nardiati, "Perian Makna Leksem 'Mengobati secara Herbal Dengan Bahan Yang Tersebut Pada Bentuk Dasarnya' Dalam Bahasa Jawa," Widyaparwa, vol. 42, no. 2, pp. 185-194, 2014.

[13] S. Nardiati, Komponen Makna "Mencuri" dan "Mencari," 1st ed. Yogyakarta: Amatera, 2018. 